\title{
Jenis Mineral Lempung Endapan Kuarter Pantai Semarang Jawa Tengah dan Potensinya sebagai Lumpur Pemboran
}

\author{
Sugeng Widada ${ }^{1)}$, Hanna Afifah ${ }^{2)}$, Salatun Said ${ }^{3)}$, Hendaryono $^{4)}$ \\ ${ }^{1,3,4)}$ Staf Pengajar Jurusan Teknik Geologi, Universitas Pembangunan Nasional "Veteran” Yogyakarta \\ ${ }^{2)}$ Alumnus Jurusan Teknik Geologi, Universitas Pembangunan Nasional "Veteran” Yogyakarta \\ Corresponding author email : swgeoupn@yahoo.co.id
}

\begin{abstract}
Abstrak
Penelitian ini bertujuan untuk mengetahui karakteristik litologi endapan Kuater Pantai Semarang yang meliputi komposisi mineralogi, distribusi serta potensinya sebagai bahan lumpur bor. Komposisi mineralogi ditentukan dengan menggunakan scanning electron microscope (SEM). Untuk mengetahui potensi sebagai lumpur bor ditentukan berdasarkan uji rheology dan filtration loss. Dari hasil analisis menunjukkan sedimen Kuater Pantai Semarang didominasi oleh endapan lempung dengan sedikit lanau pasiran yang terbentuk oleh proses pengendapan secara suspensi. Secara mineralogis, jenis mineral lempung yang dijumpai di daerah telitian sangat bervariasi. Dari analisis SEM menunjukkan jenis mineral lempung yang dijumpai antara lain kaolinit, illit dan campuran montmorilonit- illit. Berdasarkan hasil uji rheology menunjukkan pembacaan deal reading 600 RPM nilai yang dominan $=4$, harga viskositas plastis $=1$, nilai yield point $=2$ dan nilai gel strength 10 menit $=1$. Berdasarkan uji filtration loss menunjukkan volume air yang keluar rata-rata $188 \mathrm{ml}$, tebal kerak lumpur rata-rata $0,65 \mathrm{~cm}$ dan $\mathrm{pH}=8$. Berdasarkan uji rheology dan filtration loss dapat disimpulkan bahwa mineral lempung di daerah telitian tidak memenuhi kualifikasi untuk dipergunakan sebagai lumpur pemboran.
\end{abstract}

Kata kunci : Endapan Kuater Pantai Semarang, mineral lempung, komposisi mineralogi dan lumpur bor

\section{Abstract}

The objectives of this study are to identify lithological characteristics of the Quaternary Sediments in the Semarang Coast including mineralogical composition, distribution and its potency as drilling mud. Mineralogical composition is determined using scanning electron microscope (SEM). The potency as drilling mud is identified based on rheology and filtration loss tests. Based on this study shows that this sediment is predominantly composed of clay-size material with minor sandy silt-size grain deposited by suspension process. Mineralogically, there are some clay mineral type in the study area based on SEM analysis, they are kaolinite, illite and mixed montomorillonite-illite.Based on rheology test showed that the value of deal reading 600 RPM $=4$, plastic viscosity $=1$, yield point $=1$ and gel strength at 10 minute $=1$. Based on filtration loss showed the average volume expelled water $=188 \mathrm{ml}$, the average thickness of mud cake $=0.65 \mathrm{~cm}$ and $\mathrm{pH}=8$. Based on rheology and filtration loss tests can be concluded that clay sediment in the the study area can not be used as mud drilling material.

Keyword : Quaternary deposit of Semarang Coast, clay minerals, texture and mineralogy compositions.

\section{Pendahuluan}

Mineral lempung merupakan salah satu kelompok mineral kompleks yang menyusun kurang lebih $16 \%$ dari seluruh batuan sedimen penyusun kerak bumi. Berdasarkan lingkungan pengendapannya, mineral lempung dapat terbentuk baik di lingkungan darat ataupun di lingkungan laut. Mineral lempung yang terbentuk di lingkungan pantai dan lepas pantai mempunyai suatu mekanisme sedimentasi yang unik karena adanya berbagai faktor yang mempengaruhi, seperti faktor kedalaman; cahaya matahari; temperatur; topografi dan organisme. Oleh karena itu, berbagai jenis mineral lempung dapat terbentuk di lingkungan ini.

Mineral lempung merupakan salah satu jenis bahan galian yang memiliki banyak manfaat untuk berbagai macam keperluan. Mineral ini bisa digunakan sebagai bahan untuk berbagai produks keramik, genteng, batu bata, bahan baku cat, semen, lumpur pemboran dan lain-lain.

Penelitian ini bertujuan untuk mengidentifikasi jenis-jenis mineral lempung yang dijumpai di daerah telitian, pola penyebarannya serta mengetahui kelayakannya sebagai bahan untuk lumpur pemboran. Jenis-jenis mineral lempung dapat diketahui berdasarkan pengamatan petrografis sayatan tipis inti batuan dengan menggunakan metode SEM (scanning electrone micrograph). Kelayakan mineral lempung sebagai bahan lumpur pemboran ditentukan dengan Metode Rheologi dan Filtration Loss.

Daerah telitian terletak di wilayah pantai dan lepas pantai Laut Jawa, yang secara administratif merupakan bagian wilayah Kodya Semarang, Propinsi Jawa Tengah. Secara geografis daerah telitian terletak pada wilayah yang dibatasi 
koordinat $110,30^{\circ}-110,50^{\circ}$ BT dan $6,9^{\circ}-7,0^{\circ}$ LS dapat dilihat pada Gambar 1 .

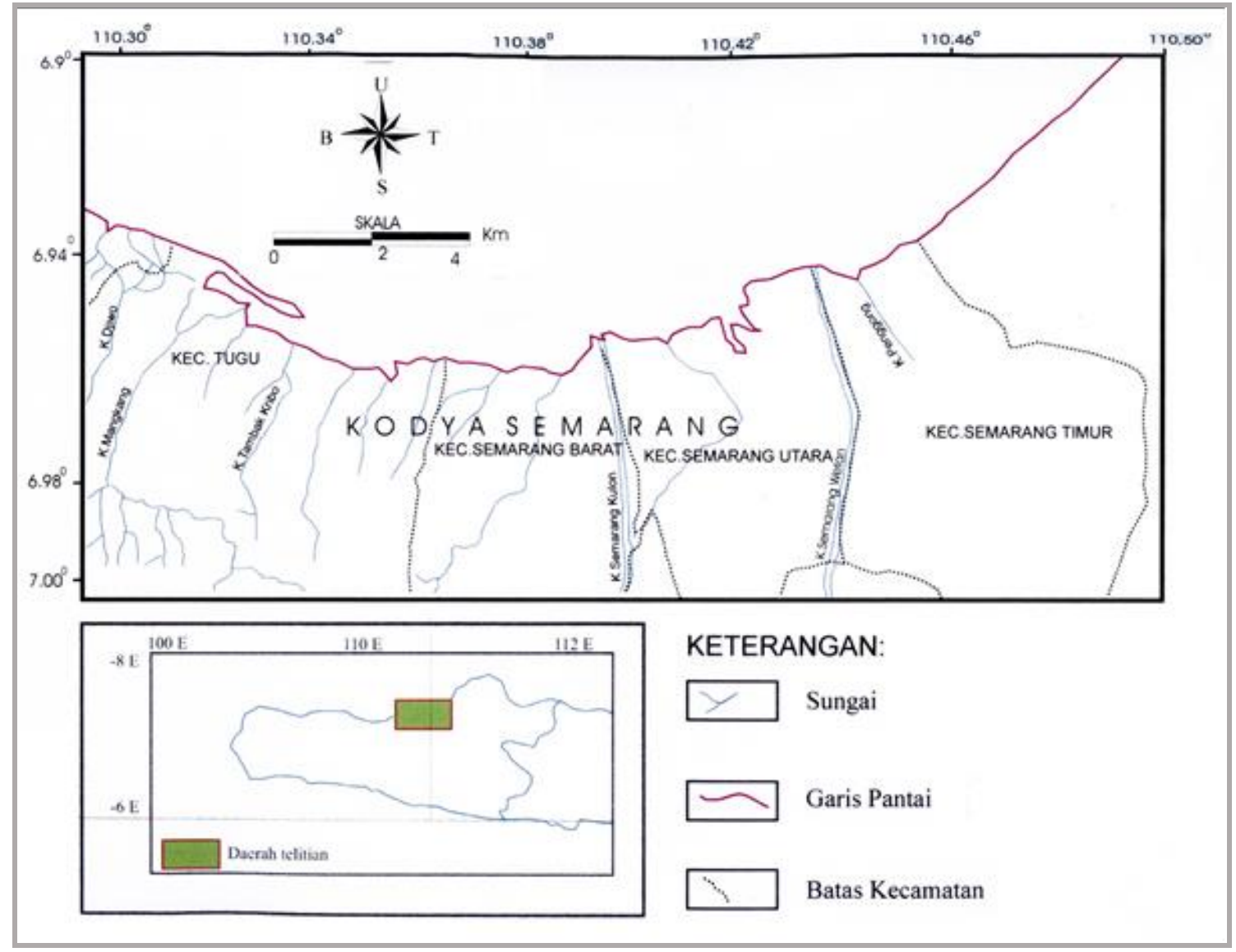

Gambar 1. Lokasi Daerah Penelitian

Van Bemmelen (1949) membagi Pulau Jawa menjadi 7 zona fisiografi, yaitu Zona Endap-an Vulkanik Kuarter, Zona Alluvial Pantai Utara, Jalur Rembang-Madura, Jalur Bogor, Serayu Utara dan Kendeng, Dome dan Pegunungan di Zona Depresi, Zona Depresi Jawa Bagian Tengah dan Zona Randublatung serta Zona Pegunungan Selatan dapat ditunjukkan pada Gambar 2.

Secara fisiografis daerah telitian merupakan bagian dari Zona Dataran Alluvial Pantai Utara yang merupakan suatu cekungan yang diisi oleh endapan aluvial pantai berumur Resen. Proses sedimentasi sedimen tersebut masih berlangsung hingga saat ini.

\subsection{Stratigrafi Regional}

Dengan mengacu pada Peta Geologi Lembar Magelang-Semarang (Thaden dkk., 1996), stratigrafi Kota Semarang dan sekitarnya tersusun oleh beberapa formasi batuan sebagai berikut :

\section{a. Formasi Kerek}

Formasi Kerek tersusun oleh perselingan batulempung, napal, batupasir tufan, konglomerat, breksi vulkanik dan batugamping. Formasi ini diendapkan pada lingkungan laut dalam pada Kala Miosen Tengah-Miosen Atas dengan ketebalan lebih dari pada 400 meter.

\section{b. Formasi Kalibeng}

Formasi Kalibeng tersusun oleh perseling-an napal, batupasir tufan, dan batugamping. Formasi ini diendapkan pada lingkungan laut pada Kala Miosen Akhir-Pliosen Tengah.

\section{c. Formasi Kaligetas}

Formasi Kaligetas tersusun oleh breksi vulkanik, aliran lava, batulempung dan batupasir tufan. Batuan vulkanik umumnya telah melapuk sangat lanjut dengan hasil pelapukan berupa lanau lempungan berwarna merah kecoklatan. Formasi ini diendapkan pada lingkungan darat pada Kala Pliosen. 


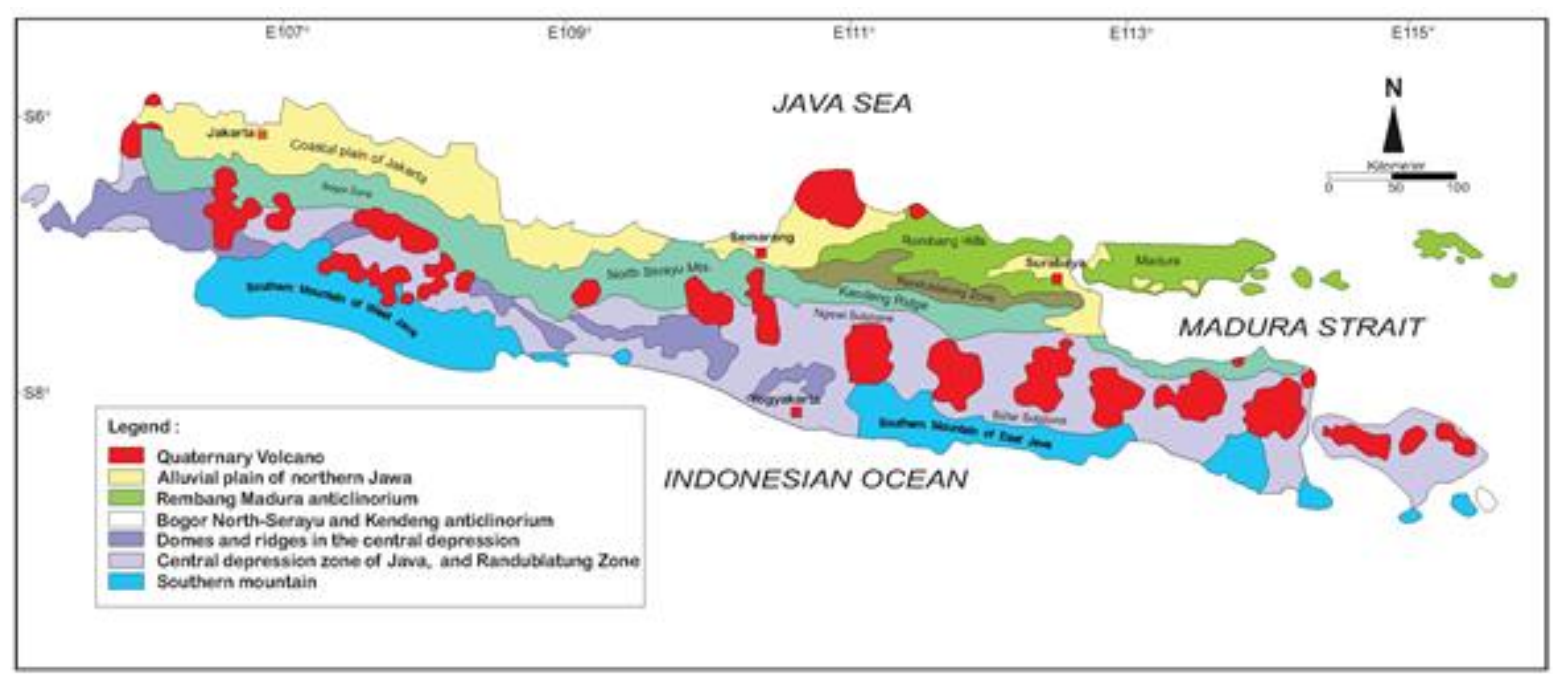

Gambar 2. Fisiografi Pulau Jawa

(Bemmelen, 1949)

\section{d. Formasi Damar}

Formasi Damar tersusun oleh perselingan batupasir tufan, konglomerat, breksi vulkanik dan tuf. Formasi ini diendapkan pada lingkungan darat sampai transisi pada Kala Pliosen.

\section{e. Alluvium}

Satuan ini terdiri dari endapan alluvium pantai, sungai dan danau. Litologi endapan alluvium pantai terdiri dari material berukuran lempung, lanau, pasir dengan ketebalan mencapai $50 \mathrm{~m}$ atau lebih.

\subsection{Mineral Lempung}

Istilah mineral lempung digunakan untuk menyebut suatu kelompok mineral yang mempunyai sifat plastis. Pettijohn (1975) mendefinisikan lempung sebagai material plastis alami yang mempunyai komposisi aluminium hidrous silikat. Dalam pengertian geologis secara umum, lempung merupakan partikel detrital dengan diameter lebih kecil daripada $1 / 256 \mathrm{~mm}$.

Mineral lempung termasuk mineral pilosilikat. Ciri khas dari mineral ini adalah mempunyai kemampuan untuk menyerap dan melepaskan air yang dikandungnya tergantung pada kondisi temperatur dan jumlah air pada saat itu. Terdapat dua jenis pilosilikat, yaitu oktahedral dan tetrahedral yang dengan berdasarkan pada hubungan antar lapisan dibagi menjadi tipe $1: 1$ dan tipe $2: 1$.

Mineral lempung bisa dibagi menjadi beberapa kelompok seperti dibahas di bawah ini.

\subsubsection{Kelompok Kaolinit-Serpentinit}

Kaolinit mempunyai tipe struktur lapisan silikat dioktahedral tipe $1: 1$ dengan komposisi kimia $\mathrm{Al}_{4} \mathrm{Si}_{4} \mathrm{O}_{10}(\mathrm{OH})_{8}$. Mineral yang termasuk dalam subkelompok kaolinit adalah kaolinit, dickite dan halloysite. Kaolinit dan dickite mempunyai morfologi lempeng sedangkan halloy-site berbentuk speroidal atau tabular.

Secara umum kaolinit merupakan mineral lempung detrital dalam sedimen yang berasal dari sumber granitik dan gneiss. Mineral ini terbentuk dari hasil proses pelapukan dan hidrotermal pada kondisi asam. Dickite dan macrite terjadi dari proses hidrotermal pada suhu rendah, halloysite terbentuk dari hasil alterasi endapan vulkanik yang berpori.

Serpentinit merupakan kaolinit trioktahedral tipe $1: 1$ dengan komposisi kimia $\mathrm{Mg}_{6} \mathrm{Si}_{4} \mathrm{O}_{10}(\mathrm{OH})_{8}$. Mineral yang termasuk dalam subkelompok serpentinit adalah chrysotile, lizardite dan amesite. Mineral ini berbentuk serabut, pipa, bilah dan lempeng, kejadiannya berhubungan dengan proses alterasi batuan ultra basa pada suhu sekitar $450^{\circ} \mathrm{C}$.

\subsubsection{Kelompok Mika}

Mika mempunyai tipe struktur lapisan $1: 1$ yang dibentuk oleh lembaran silikon-oksigen tetrahedral berlapis-lapis dengan sebuah lembaran oktahedral. Mineral dari kelompok ini yang paling banyak dijumpai pada endapan lempungan adalah tipe mika potassium yang biasa disebut sebagai illite. 
Illite merupakan mineral yang banyak dijumpai baik pada sedimen laut Resen ataupun sedimen masa lampau. Mineral ini dapat terbentuk dari proses pelapukan di dalam tanah atau transformasi mineral sebelumnya. Adanya potassium dalam illite bisa disebabkan oleh degradasi KFeldspar pada kaolinit yang belum selesai atau karena diagenesa kaolinit dalam lingkungan laut.

\subsubsection{Kelompok Smectite}

Mineral yang termasuk dalam kelompok ini mempunyai tipe struktur lapisan $2: 1$. Smectite dibagi menjadi 2 subkelompok, yaitu dioktahedral dan trioktahedral. Mineral yang termasuk dalam subkelompok dioktahedral yaitu montmorillonite dan badellite, sedangkan yang termasuk dalam subkelompok trioktahedral yaitu saponite, hectorite dan sauconite.

Smectite dapat terbentuk dalam tanah tropis dari hasil presipitasi larutan (smectite neoform) atau dari hasil transformasi mineral silika lainnya (smectite terdegradasi). Pelapukan gelas vulkanik merupakan proses penting pembentukan smectite pada kondisi lingkungan tropis.

\subsubsection{Kelompok Khlorite}

Mineral yang termasuk dalam kelompok ini mempunyai tipe struktur lapisan $2: 1$. Khlorit dibagi menjadi 3 subkelompok, yaitu dioktahedral, di-trioktahedral dan trioktahedral khlorite. Sebagian besar khlorite terbentuk oleh proses metamorfisme tingkat rendah dan jarang terbentuk oleh proses sedimentasi di lingkungan darat ataupun laut.

\subsubsection{Kelompok Pyrophyllite-Talc}

Mineral yang termasuk dalam kelompok pyrophyllite mempunyai tipe struktur lapisan silikat $2: 1$ dengan komposisi kimia $\mathrm{Al}_{4} \mathrm{Si}_{8} \mathrm{O}_{20}(\mathrm{OH})_{4}$. Mineral ini jarang dijumpai pada batuan sedimen tetapi banyak terdapat pada batuan metamorf di lingkungan hidrotermal. Talc merupakan kelompok mineral yang mempunyai struktur trioktahedral dengan komposisi kimia $\mathrm{Al}_{6} \mathrm{Si}_{8} \mathrm{O}_{20}(\mathrm{OH})_{4}$. Mineral ini terbentuk oleh proses metamorfisme pada suhu rendah dan berasosiasi dengan hidrotermal.

\subsubsection{Kelompok Vermiculite}

Mineral yang termasuk dalam kelompok ini mempunyai tipe struktur lapisan $2: 1$. Vermiculite dibagi menjadi 2 subkelompok, yaitu dioktahedral dan trioktahedral vermiculite. Mineral ini merupakan hasil alterasi muskovit, biotit atau mineral pilosilikat lainnya.

\subsection{Lumpur Pemboran}

Lumpur pemboran merupakan campuran antara bahan pelarut, baik air atau minyak, dengan material-material tertentu yang sangat dibutuhkan dalam proses pemboran. Dalam operasi pemboran lumpur bor mempunyai beberapa manfaat antara lain : mengangkat serbuk bor ke permukaan, mengontrol tekanan formasi, mendinginkan dan melumasi bit dan drill string, melepas serbuk bor dan pasir di permukaan serta sebagai media logging.

Ada beberapa sifat fisik lumpur pemboran yang selalu dikontrol pada setiap operasi pemboran migas dan panas bumi yaitu : densitas, rheologi (sifat aliran) dan filtration loss. Dalam proses pemboran densitas lumpur bor selalu dikontrol untuk menjaga tekanan lubang bor. Lumpur yang terlalu berat dapat menyebabkan terjadinya losst circulation, lumpur yang terlalu ringan menyebabkan masuknya fluida formasi ke dalam lubang bor (kick) dan jika tidak segera diatasi dapat menyebabkan terjadinya semburan liar (blow out).

Rheologi merupakan ilmu yang mempe-lajari perubahan bentuk dan aliran dari suatu fluida. Pengontrolan rheologi diperlukan untuk pengangkatan serbuk bor pada saat pemboran berlangsung. Dalam hal ini rheologi meliputi viskositas, shear rate dan shear stress, viskositas plastik, yield point, apparent viscosity dan gel strength. Data rheologi didapatkan dari hasil pengukuran viskometer yang memberikan data dial reading. Filtration loss adalah kehilangan sebagian cairan (filtrat) lumpur masuk ke dalam formasi permeabel. Faktor-faktor yang mempengaruhi sifat tersebut adalah waktu filtrasi, suhu, konsentrasi padatan, permeabilitas kerak lumpur pemboran dan jenis lumpur. Filtration loss yang besar pada operasi pemboran mengakibatkan sistem lumpur akan kehilangan komponen cairnya, juga menyebabkan terjadinya formation damage karena mengecilnya porositas dan permeabilitas efektif terhadap minyak dan gas. Spesifikasi bentonit sebagai lunpur pemboran ditunjukkan pada Tabel 1. 
Tabel 1. Spesifikasi Bentonit sebagai Lumpur Pemboran

\begin{tabular}{|l|l|}
\hline \multicolumn{1}{|c|}{ Requirement } & \multicolumn{1}{c|}{ API Standard } \\
\hline Viscosimeter dial reading @600 RPM & Minimum 30 cp \\
Plastic viscosity, cp & Minimum $8 \mathrm{cp}$ \\
Yield point, lb/100 $\mathrm{ft}^{2}$ & Maksimum 3 PV \\
Filttrate, cc/30 minutes & Maksimum 13,5 \\
Wet screen analysis residu & Maksimum 2,5\% \\
On US Sieve No. 200 moisture & $10 \%$ maximum as shipped from point of manucfature \\
Yield & 91,8 bbls of 15 cp mud per ton of dry \\
\hline
\end{tabular}

\section{Metodologi}

Sebanyak 13 sampel inti bor (SW 8, SW 9, SW 10, SW 11, SW 17, SW 18, SW 19, SW 20, SW 21, SW 27, SW 28, SW 29 dan SW 30) diambil dari kawasan pantai dan lepas pantai Kota Semarang yang selanjutnya dianalisis jenis mineral penyusunnya dengan menggunakan metoda SEM.

\section{Hasil dan Pembahasan}

Metode SEM merupakan suatu metoda yang dapat memberikan gambaran tiga dimensional jenis mineral lempung yang diamati.

\subsection{Jenis Mineral dan Pola Distribusi}

Dari pengamatan inti batuan secara megaskopis menunjukkan sebagian besar sampel berupa lempung yang belum terlitifikasi, berwarna coklat tua; abu-abu hingga abu-abu tua, sangat lunak hingga lunak, basah sampai jenuh air, tidak plastis sampai plastisitas sedang, porositas baik, permeabilitas jelek, komposisi didominasi oleh mineral lempung dengan sedikit kandungan fragmen pelecypoda; gastropoda dan foraminifera baik dalam keadaan utuh atau rusak, fragmen batuan, kuarsa, feldspar serta mineral bijih.

Dari analisis SEM menunjukkan ada 3 jenis mineral lempung yang dijumpai di daerah telitian, yaitu kaolinit, illite dan mixed layer-clay montmorilonite-illite. Distribusi dari masingmasing mineral mempunyai pola khas dan ditunjukkan pada Gambar 3.

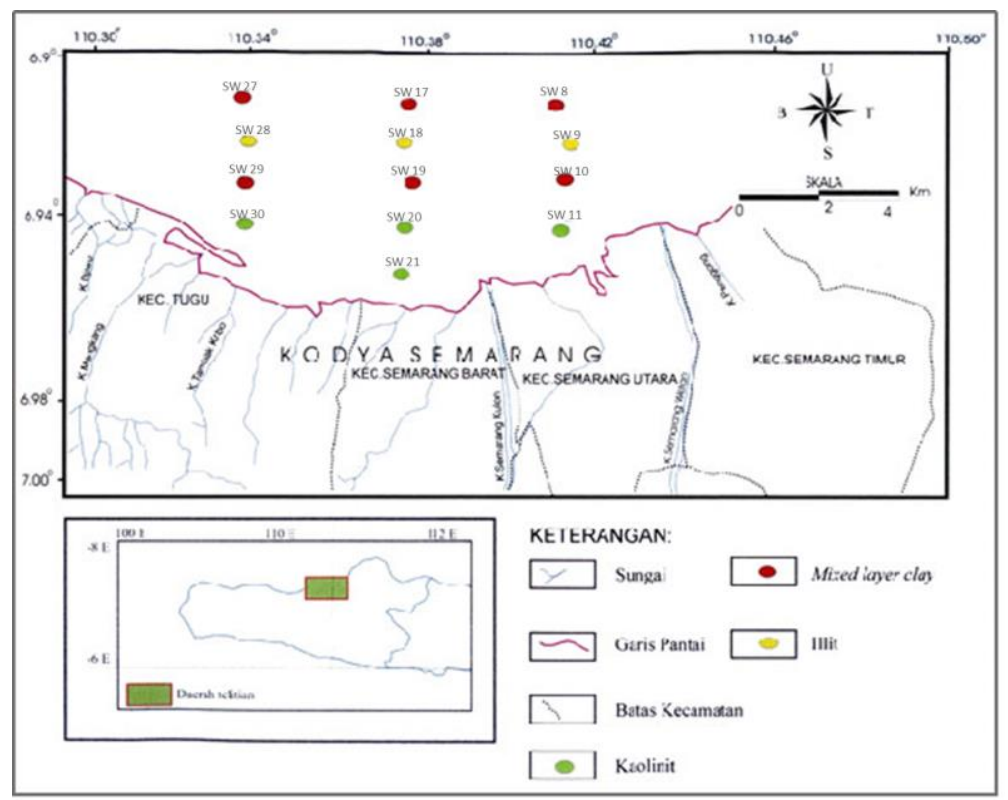

Gambar 3. Peta distribusi mineral lempung

Mineral kaolinit dijumpai pada sampel SW 11, SW 20, SW 21 dan SW 30 pada gambar Gambar 4. Dari hasil analisis menunjukkan jenis mineral ini dijumpai pada daerah pantai dan perairan dekat pantai serta diperkirakan merupakan jenis mineral lempung yang pertama kali terbentuk di daerah penelitian. 


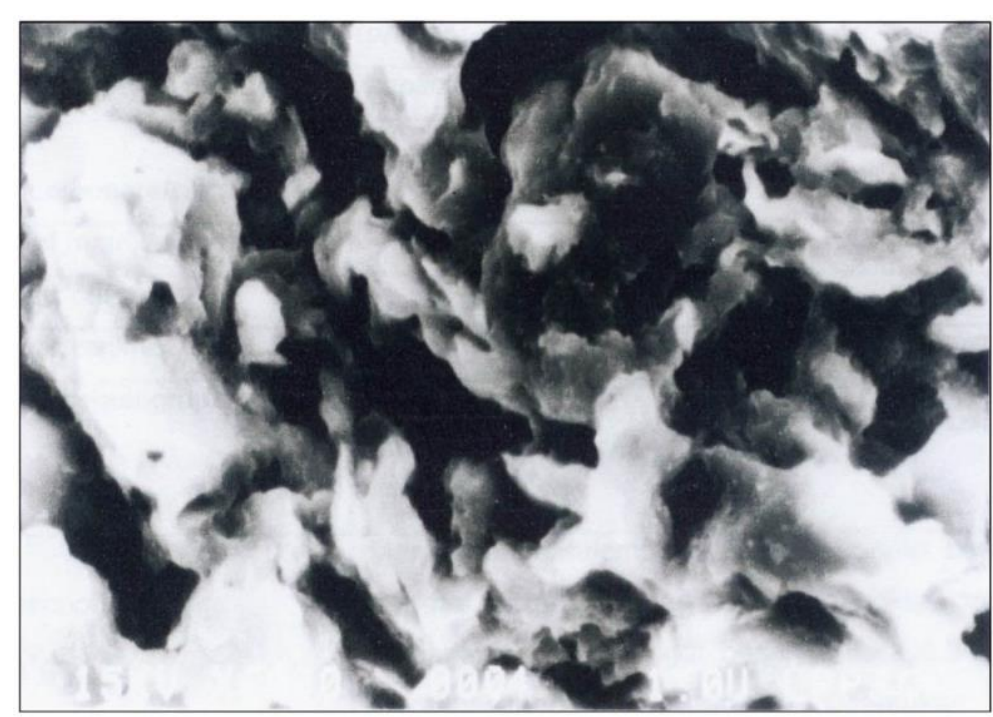

Gambar 4. Foto SEM mineral kaolinit pada sampel SW 20

Mineral illite dijumpai pada sampel SW 8, SW 9, SW 18 dan SW 28 ditunjukkan pada Gambar 5. Mineral illite mempunyai bentuk yang khas, yaitu akan memberikan gambaran 3 dimensi dengan bentuk seperti rambut yang tidak menerus dan secara umum merupakan massa dasar yang

dijumpai bersama dengan fragmen batuan, mineral ataupun fragmen fosil. Dari hasil analisis menunjukkan jenis mineral ini dijumpai pada daerah perairan yang lebih dalam serta merupakan jenis mineral yang distribusinya paling luas di daerah telitian.

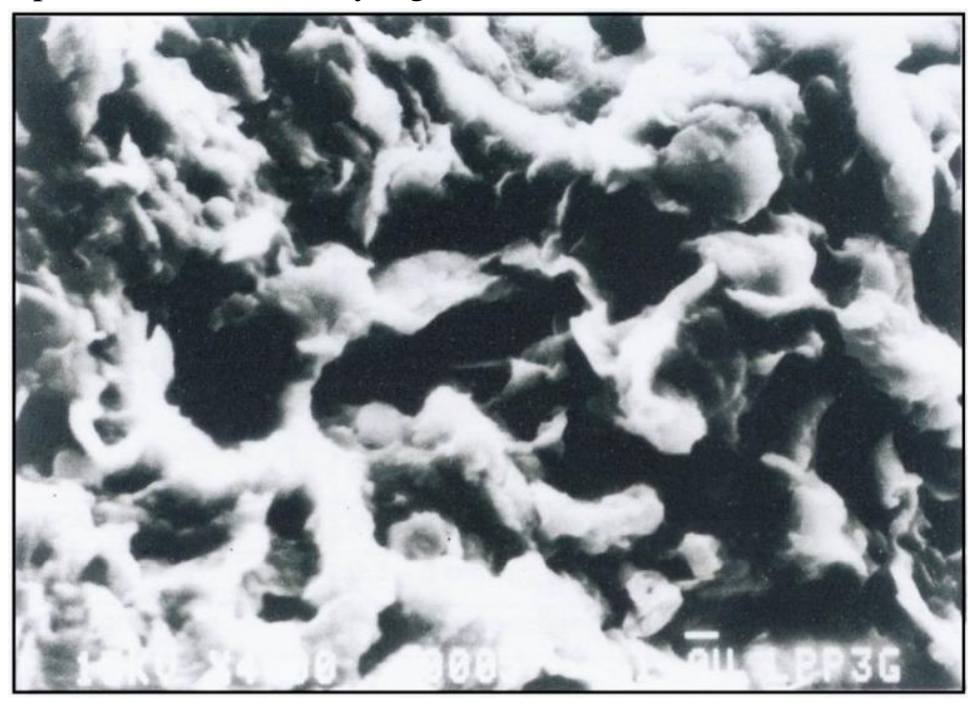

Gambar 5. Foto SEM mineral illite pada sampel SW 8

Mineral mixed layer-clay montmoriloniteillite dijumpai pada sampel SW 8, SW 10, SW 17, SW 19, SW 27 dan SW 29 ditunjukkan pada Gambar 6. Mineral montmorilonite mempunyai bentuk yang khas, yaitu akan memberikan gambaran 3 dimensi dengan bentuk seperti gumpalan terang yang berkelok-kelok dan dijumpai bersama dengan fragmen batuan, mineral ataupun fragmen fosil. Dari hasil analisis menunjukkan jenis mineral ini dijumpai pada daerah perairan yang lebih dalam. Mineral montmorillonite merupakan jenis mineral lempung yang biasa digunakan sebagai bahan lumpur pemboran dan dalam dunia industri diberi nama bentonite. 


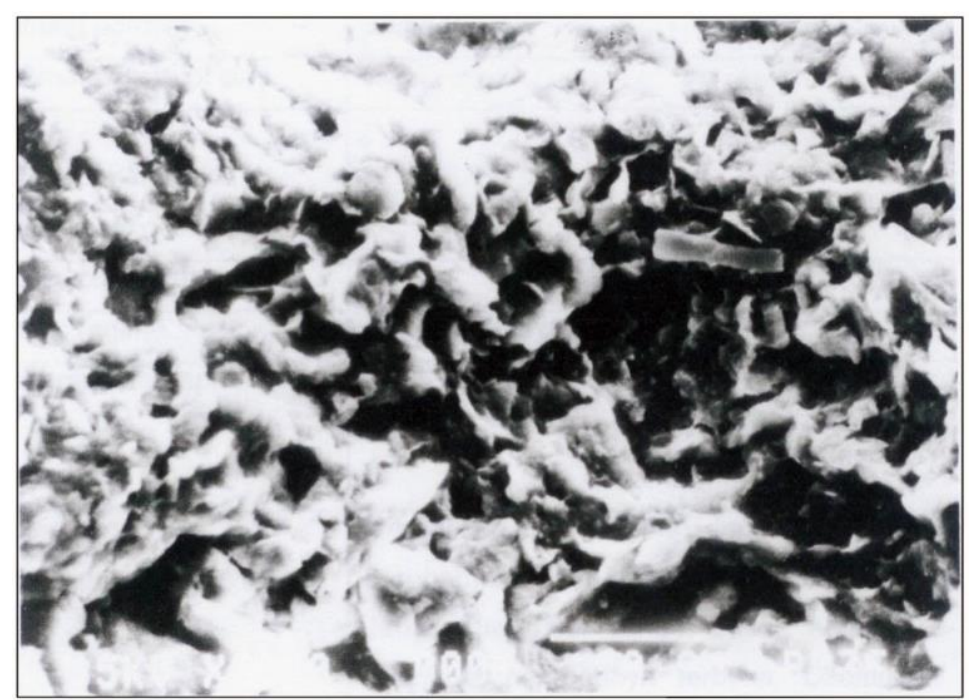

Gambar 6. Foto SEM mineral mixed layer-clay montmorilonite-illite pada sampel SW 27

\subsection{Potensi Lempung untuk Lumpur Pemboran}

Untuk menganalisis potensi lempung di daerah telitian sebagai bahan campuran untuk lumpur pemboran, lempung dicampur dengan aquades kemudian dilakukan uji rheologi dan filtration loss. Hasil uji rheology dan filtration loss dibahas di bawah ini.

\subsubsection{Uji Rheologi}

Uji rheologi yang dilakukan pada penelitian ini meliputi beberapa analisis antara lain proses pencampuran mineral lempung yang bertujuan untuk mencari nilai shear stress, shear rate, viskositas nyata, viskositas plastis, gel strength dan yield point dengan memakai persamaan Bingham Plastic. Perhitungan nilai-nilai tersebut didasarkan pada data dial reading (Tabel 2) yang diperoleh dari pengukuran viskometer. Nilai shear stress diperoleh dari persamaan $\tau=5,077 \mathrm{x}$ $\mathrm{C}$, shear rate diperoleh dari rumus : $\gamma=1,704 \mathrm{x}$ RPM, nilai viskositas nyata diperolreh dari formula : $\mu \mathrm{a}=(300 \times \mathrm{C}) \times \mathrm{RPM}$, viskositas plastik diperoleh dari rumus : $\mu \mathrm{p}=\mathrm{C}_{600}-\mathrm{C}_{300}$, harga yield point dihitung berdasarkan rumus $: \mathrm{yb}$ $=\mathrm{C}_{300}-\mu \mathrm{p}$. Gel strength diperoleh dari data dial reading 600 RPM yang didiamkan selama 10 detik dan 10 menit.

Tabel 2. Data deal reading dalam satuan derajad

\begin{tabular}{|c|c|c|c|c|c|c|}
\hline $\begin{array}{c}\text { Nomor } \\
\text { Conto }\end{array}$ & $\begin{array}{c}\mathbf{6 0 0} \\
\text { RPM }\end{array}$ & $\mathbf{3 0 0}$ RPM & $\mathbf{2 0 0}$ RPM & $\mathbf{1 0 0}$ RPM & $\begin{array}{c}\mathbf{6} \\
\text { RPM }\end{array}$ & $\begin{array}{c}\mathbf{1} \\
\text { RPM }\end{array}$ \\
\hline SW 8 & 4 & 3 & 2 & 1 & 0,5 & 0,5 \\
\hline SW 9 & 3 & 2 & 2 & 1 & 1 & 0,5 \\
\hline SW 10 & 4 & 3 & 2 & 1 & 0,5 & 0,5 \\
\hline SW 11 & 4 & 2 & 2 & 1 & 0,5 & 0,5 \\
\hline SW 27 & 4 & 3 & 2 & 1 & 1 & 0,5 \\
\hline SW 28 & 4 & 3 & 2 & 1 & 0,5 & 0,5 \\
\hline SW 29 & 4 & 2 & 2 & 1 & 0,5 & 0,5 \\
\hline SW 30 & 4 & 2 & 2 & 1 & 0,5 & 0,5 \\
\hline
\end{tabular}

Hasil perhitungan semua parameter dalam uji rheologi ditunjukkan pada Tabel 3, 4, 5, 6 dan 7.

Hasil uji laboratorium menunjukkan pembacaan dial reading @600 RPM (Tabel 2) nilai yang dominan adalah 4 derajad, harga viskositas plastis $=1$ centipoise $($ Tabel 6$)$ dan nilai yield point $=2$ (Tabel 6). Berdasarkan standard API untuk bisa digunakan sebagai lumpur pemboran harus memenuhi syarat sebagai berikut : deal reading @600 RPM = minimum 30, viskositas plastis $=$ minimum 8 centipoise, yield point $=$ maksimum $3 \mathrm{PV}$. Hal ini menunjukkan bahwa lumpur yang dibuat dari mineral lempung daerah telitian dengan aquades tidak memenuhi standard untuk dijadikan lumpur pemboran. Dengan nilai viskositas yang sangat rendah seperti lumpur telitian akan menyebabkan terjadinya penetration rate turun, pressure loss menjadi sangat tinggi, 
lumpur pemboran akan sulit melepaskan serbuk bor dan beban pada pompa akan bertambah berat.

Tabel 3. Data shear stress dalam satuan dyne $/ \mathrm{cm}^{2}$

\begin{tabular}{|c|c|c|c|c|c|c|}
\hline $\begin{array}{c}\text { Nomor } \\
\text { Conto }\end{array}$ & $\mathbf{6 0 0}$ RPM & $\mathbf{3 0 0}$ RPM & $\mathbf{2 0 0}$ RPM & 100 RPM & 6 RPM & 1 RPM \\
\hline SW 8 & 20,30 & 15,23 & 10,15 & 5,08 & 2,54 & 2,54 \\
\hline SW 9 & 15,23 & 10,15 & 10,15 & 5,08 & 5,08 & 2,54 \\
\hline SW 10 & 20,30 & 15,32 & 10,15 & 5,08 & 2,54 & 2,54 \\
\hline SW 11 & 20,30 & 10,15 & 10,15 & 5,08 & 2,54 & 2,54 \\
\hline SW 27 & 20,30 & 15,32 & 10,15 & 5,08 & 5,08 & 2,54 \\
\hline SW 28 & 20,30 & 15,32 & 10,15 & 5,08 & 2,54 & 2,54 \\
\hline SW 29 & 20,30 & 10,15 & 10,15 & 5,08 & 2,54 & 2,54 \\
\hline SW 30 & 20,30 & 10,15 & 10,15 & 5,08 & 2,54 & 2,54 \\
\hline
\end{tabular}

Tabel 4. Data shear rate dalam satuan $\operatorname{detik}^{-1}$

\begin{tabular}{|c|c|c|c|c|c|c|}
\hline $\begin{array}{c}\text { Nomor } \\
\text { Conto }\end{array}$ & $\begin{array}{c}\mathbf{6 0 0} \\
\text { RPM }\end{array}$ & $\mathbf{3 0 0} \mathbf{R P M}$ & $\mathbf{2 0 0} \mathbf{R P M}$ & $\mathbf{1 0 0} \mathbf{R P M}$ & $\begin{array}{c}\mathbf{6} \\
\mathbf{R P M}\end{array}$ & $\begin{array}{c}\mathbf{1} \\
\mathbf{R P M}\end{array}$ \\
\hline SW 8 & 6,82 & 5,11 & 3,41 & 1,70 & 0,85 & 0,50 \\
\hline SW 9 & 5,12 & 3,41 & 3,41 &, 70 & 1,70 & 0,50 \\
\hline SW 10 & 6,82 & 5,11 & 3,41 & 1,70 & 0,85 & 0,50 \\
\hline SW 11 & 6,82 & 3,41 & 3,41 & 1,70 & 0,85 & 0,50 \\
\hline SW 27 & 6,82 & 5,11 & 3,41 & 1,70 & 1,70 & 0,50 \\
\hline SW 28 & 6,82 & 5,11 & 3,41 & 1,70 & 0,85 & 0,50 \\
\hline SW 29 & 6,82 & 3,41 & 3,41 & 1,70 & 0,85 & 0,50 \\
\hline SW 30 & 6,82 & 3,41 & 3,41 & 1,70 & 0,85 & 0,50 \\
\hline
\end{tabular}

Tabel 5. Data viskositas nyata dalam satuan centipoise

\begin{tabular}{|c|c|c|c|c|c|c|}
\hline $\begin{array}{c}\text { Nomor } \\
\text { Conto }\end{array}$ & $\mathbf{6 0 0}$ RPM & $\mathbf{3 0 0}$ RPM & $\mathbf{2 0 0}$ RPM & 100 RPM & 6 RPM & 1 RPM \\
\hline SW 8 & 2 & 4 & 3 & 3 & 25 & 25 \\
\hline SW 9 & 1,5 & 2 & 3 & 3 & 50 & 25 \\
\hline SW 10 & 2 & 4 & 3 & 3 & 25 & 25 \\
\hline SW 11 & 2 & 2 & 3 & 3 & 25 & 25 \\
\hline SW 27 & 2 & 4 & 3 & 3 & 50 & 25 \\
\hline SW 28 & 2 & 4 & 3 & 3 & 50 & 25 \\
\hline SW 29 & 2 & 3 & 3 & 3 & 25 & 25 \\
\hline SW 30 & 2 & 2 & 3 & 3 & 25 & 25 \\
\hline
\end{tabular}

Tabel 6. Hasil perhitungan nilai $\mu$ p (viskositas plastis) dan yb (yield point)

\begin{tabular}{|c|c|c|}
\hline $\begin{array}{c}\text { Nomor } \\
\text { Conto }\end{array}$ & $\begin{array}{c}\mu p \\
\text { (centipoise) }\end{array}$ & $\begin{array}{c}\text { Yb } \\
(1 \mathrm{lb} / 100 \\
\mathrm{ft} 2)\end{array}$ \\
\hline SW 8 & 1 & 2 \\
\hline SW 9 & 1 & 1 \\
\hline SW 10 & 1 & 2 \\
\hline SW 11 & 2 & 0 \\
\hline SW 27 & 1 & 2 \\
\hline SW 28 & 1 & 2 \\
\hline SW 29 & 1 & 1 \\
\hline SW 30 & 2 & 0 \\
\hline
\end{tabular}


Tabel 7. Hasil pengamatan gel strength dalam satuan $100 \mathrm{lb} / \mathrm{ft}^{2}$

\begin{tabular}{|c|c|c|}
\hline Nomor Conto & 10 Detik & 10 Menit \\
\hline SW 8 & 0,5 & 1 \\
\hline SW 9 & 0,5 & 1 \\
\hline SW 10 & 0,5 & 1 \\
\hline SW 11 & 0,5 & 1 \\
\hline SW 27 & 0,5 & 1 \\
\hline SW 28 & 0,5 & 1 \\
\hline SW 29 & 0,5 & 1 \\
\hline
\end{tabular}

Tabel 8. Hasil uji filtration loss

\begin{tabular}{|c|c|c|c|}
\hline $\begin{array}{c}\text { Nomor } \\
\text { Conto }\end{array}$ & $\begin{array}{c}\text { Volume } \\
(\mathbf{m l})\end{array}$ & $\begin{array}{c}\text { Tebal Kerak Lumpur } \\
\text { (cm) }\end{array}$ & $\mathbf{p H}$ \\
\hline SW 8 & 180 & 0,67 & 8 \\
\hline SW 9 & 230 & 0,55 & 8 \\
\hline SW 10 & 170 & 0,60 & 8 \\
\hline SW 11 & 180 & 0,67 & 8 \\
\hline SW 27 & 190 & 0,69 & 8 \\
\hline SW 28 & 190 & 0,70 & 8 \\
\hline SW 20 & 180 & 0,66 & 8 \\
\hline SW 30 & 185 & 0,68 & 8 \\
\hline
\end{tabular}

Kemampuan lumpur untuk menahan serbuk bor selama sirkulasi dihentikan terutama tergantung pada gel strength. Cairan menjadi gel, tekanan ke bawah akan meningkat. Serbuk bor perlu ditahan agar tidak turun ke bawah karena bila mengendap dapat mengakibatkan akumulasi serbuk bor dan pipa akan terjepit. Selain itu hal tersebut akan memperberat rotasi permulaan dan juga memperberat kerja pompa untuk memulai sirkulasi kembali. Tetapi gel strength yang terlalu besar akan berakibat buruk juga karena akan menahan pembuangan serbuk bor di permukaan. Dari hasil analisis menunjukkan harga gel strength pada 10 menit $=1$.

\subsubsection{Uji Filtration Loss}

Uji filtration loss dilakukan untuk mencari tebal kerak lumpur yang terbentuk, jumlah volume air yang keluar serta $\mathrm{pH}$ filtrat. Hasil pengujian filtration loss lumpur di daerah telitian ditunjukkan pada Tabel 7. Dari tabel tersebut menunjukkan volume air yang keluar rata-rata 188 $\mathrm{ml}$, tebal kerak lumpur rata-rata $0,65 \mathrm{~cm}$ dan $\mathrm{pH}=$ 8.

Berdasarkan hasil tersebut dapat disimpulkan dengan banyaknya volume air yang keluar dari lumpur pada saat diberi tekanan maka lumpur di daerah telitian sangat jelek kualitasnya. Fungsi dari filtrat lumpur adalah untuk mengikis kerak lumpur yang terbentuk pada lubang pemboran. Apabila kerak lumpur yang terbentuk sangat tebal akan mengakibatkan kegiatan pem- boran tidak dapat dilanjutkan karena sirkulasi pemboran terhambat. Pembentukan kerak lumpur ini akan menyebabkan tertahannya aliran fluida masuk ke dalam formasi. Adanya aliran yang masuk, yaitu cairan dan padatan menyebabkan padatan tersaring. Cairan yang masuk ke dalam formasi disebut filtrat.

Filtration loss yang besar pada operasi pemboran mengakibatkan sistem lumpur akan kehilangan komponen cairnya, juga menyebabkan terjadinya formation damage. Hal itu menyebabkan berkurangnya harga porositas dan permeabilitas efektif terhadap minyak dan gas. Kerak lumpur bor yang terbentuk sebaiknya tipis, impermeabel, elastis dan plastis untuk menghindari terjadinya jepitan, pressure surge swabbing.

Dari hasil penelitian menunjukkan $\mathrm{pH}$ dari lumpur telitian adalah 8 ditunjukkan pada Tabel 8 , sedangkan $\mathrm{pH}$ yang baik untuk lumpur pemboran adalah $\mathrm{pH}$ dengan nilai di atas 10 (Standar API). Dengan $\mathrm{pH}=8$ akan menyebabkan terjadinya korosi oleh gas hidrogen sulfida, suhu menjadi tidak stabil, menurunkan batas toleransi untuk terbentuknya high solid content dan akan menambah kontaminasi.

Berdasarkan hasil uji rheology dan filtration loss seperti dijelaskan di atas dapat disimpulkan bahwa dengan menggunakan pelarut aquades lempung di daerah telitian tidak memenuhi persyaratan untuk dijadikan lumpur pemboran. Perlu ditambahkan bahan additive untuk meningkatkan kualitas lempung di daerah telitian sehing- 
ga bisa dimanfaatkan sebagai bahan lumpur pemboran.

\section{Kesimpulan}

1. Berdasarkan analisis SEM menunjukkan jenis mineral lempung yang dijumpai di daerah telitian antara lain kaolinit, illit dan campuran montmorilonit- illit.

2. Dari hasil analisis menunjukkan jenis mineral kaolinit dijumpai pada daerah pantai dan perairan dekat pantai serta diperkirakan merupakan jenis mineral lempung yang pertama kali terbentuk di daerah penelitian.

3. Mineral illite dan mixed layer-clay montmorilonite-illite dijumpai pada perairan yang lebih dalam. Mineral illite merupakan jenis mineral yang mempunyai distribusi paling luas di daerah telitian.

4. Dengan menggunakan pelarut aquades lempung di daerah telitian tidak layak digunakan sebagai lumpur pemboran.

\section{Daftar Pustaka}

Carlin, C., 1950. Petroleum Enginering-Drilling and Well Completion, Prentice Hall Inc., Englewood Cliffs, New York.
Hana Afifah, 2005. Analisis Mineral Lempung Pantai Kodya Semarang Untuk Lumpur Pemboran, Laporan Skripsi, Universitas Pembangunan Nasional "Veteran" Yogyakarta.

Klein, C. and Hurbut, C., 1985. Systematic Mineralogy Part IV, Silisiclastic Manual of Mineralogy $20^{\text {th }}$ Ed., John Willey and Sons, New York.

Lummus, J.L . and Azzaz, J.J., 1986. Drilling Fluids Optimation, A Practical Field Approach, Penn-Well Publishing Co.

Pettijohn, F.J., 1975. Sedimentary Rocks, $3^{\text {rd }}$ edition. Harper and Row, New York.

Rubiandini, Rudi R.S., 1986. Diktat Kursus - Mud Design and Problem Solving, PT Redekatama Mitra.

Thaden, R.E., Sumadirdja, H. Richards., P.W. 1996. Peta Geologi Lembar Magelang dan Semarang, Jawa, 1:250.000, Geological Survey of Indonesia.

Van Bemmelen, R.W., 1949. The Geology of Indonesia, 1A, Martinus Nijhoff, The Hague. 